\title{
Perubahan Luas Penutupan Padang Lamun Di Kepulauan Seribu, DKI Jakarta
}

\author{
Alteration of Seagrass Coverage in Seribu Islands, DKI Jakarta \\ Mujizat Kawaroe*, Indra Jaya, Indarto H.S., Dahlia Wulan Sari, dan Sundari Wening W. \\ Laboratorium Hidrobiologi Laut, Fakultas Perikanan dan Ilmu Kelautan, Institut Pertanian Bogor \\ Jl. Lingkar Akademik No.1 Kampus IPB DARMAGA, Bogor Indonesia 16680 \\ E-mail: ds_biolal@yahoo.com *Penulis untuk korespondensi
}

\begin{abstract}
Seagrass is one of productive and economical marine ecosystem, but recently there are indications that this area is decreasing and every kind of damage is happening. The research was conducted to reveal the change of seagrass width area and to determine the suitable location for donor and acceptor of seagrass transplantation. Methods of research were collecting and analyzing the satellite image of the research location, bathymetri mapping and water quality parameter, and also determining environment charasteristics that suitable to be performed by counting Seagrass Transplantation Suitability Index (STSI). The results show that in year 19992004, the derivation area of seagrass was $678.300 \mathrm{~m}^{2}$. Pari island has depth range between 0-50 metres and the physics and chemical parameter of water have a good range where the seagrass can live. According to the analysis result of STSI, suitable areas for seagrass transplantation donor is station no. 5 and 6 for seagrass species of Enhalus acoroides and station no. 2 and 7 for seagrass species Thalassia hemprichii. The implication of this research is that the seagrass needs rehabilitation to overcome seagrass ecosystem for better condition.
\end{abstract}

Key words: Seagrass, transplantation, bathymetri, Coverage

Abstrak

Padang lamun merupakan ekosistem laut produktif dan bernilai ekonomis, tetapi saat ini ada indikasi bahwa luasan padang lamun semakin berkurang dan berbagai kerusakan terjadi pada ekosistem ini. Penelitian ini dilakukan guna mengetahui perubahan luasan padang lamun dan untuk menentukan lokasi yang sesuai untuk donor dan penerima transplantasi lamun. Penelitian dilakukan dengan mengumpulkan dan menganalisis citra satelit lokasi penelitian, pemetaan batimetrinya dan parameter kualitas perairan. Untuk menentukan karakteristik lingkungan yang sesuai dilakukan dengan menghitung Indeks Kesesuaian Transplantasi Lamun (IKTL). Hasil penelitian menunjukkan bahwa tahun 1999- 2004, penurunan luasan padang lamun sebesar $678,300 \mathrm{~m}^{2}$. Gugus Pulau Pari memiliki kedalaman perairan antara 0 meter hingga 50 meter dan nilai parameter fisika kimia perairan memiliki kisaran lamun dapat tumbuh dengan baik. Hasil analisis IKTL lokasi yang sesuai untuk donor transplantasi lamun adalah stasiun 5 dan 6 untuk lamun jenis Enhalus acoroides serta stasiun 2 dan 7 untuk lamun jenis Thalassia hemprichii. Implikasi penelitian ini adalah ekosistem padang lamun membutuhkan rehabilitasi untuk memperbaiki kondisi ekosistemnya menjadi lebih baik.

Kata kunci: Lamun, trasplantasi, batimetri, luas penutupan

Diterima: 30 Maret 2009, disetujui: 01 Desember 2009

Pendahuluan
Padang lamun sudah sejak lama diketahui memiliki nilai ekologi dan ekonomi yang sangat penting. Bersama ekosistem mangrove dan 
terumbu karang, padang lamun tidak hanya merupakan ekosistem yang memiliki produktivitas primer tinggi (Borum et al., 2006) dan siklus nutrient (Romero et al., 2006) tetapi juga menyediakan habitat untuk kehidupan berbagai macam organisme laut (Duarte, 2002), serta dapat meningkatkan kestabilan substrat melalui perluasan akarnya secara ekstensif (Fonseca dan Fisher, 1986). Akhir-akhir ini secara visual terlihat ada indikasi luasan padang lamun mengalami penurunan. Walaupun di beberapa lokasi penurunan luasan ini diakibatkan oleh kondisi alam (Robblee et al., 1991; Preen et al., 1995; den Hartog, 1996; Seddon et al., 2000), penyebab utama penurunan ini adalah karena faktor antropogenik (Short dan Wyllie-Echeverria, 1996; Seddon et al., 2003; Walker et al., 2006). Mengingat bahwa peningkatan populasi manusia semakin cepat dan memiliki kecenderungan untuk menempati wilayah pesisir maka ancaman terhadap keberadaan padang lamun menjadi semakin mengkhawatirkan.

Secara global dalam dua decade (1990-2000) diperkirakan penurunan luasan padang lamun mencapai $18 \%\left(33.000 \mathrm{~km}^{2}\right)$ yang diakibatkan oleh aktivitas manusia secara langsung (Walker et al., 2006). Walaupun telah banyak penelitian yang menunjukkan penurunan luasan tersebut, pemulihan terhadap kerusakan padang lamun masih sangat jarang dilakukan. Salah satu alasan yang mendasari ketidakseimbangan antara kerusakan dan proses pemulihan lamun adalah masalah waktu. Kerusakan lamun, baik fisik maupun fisiologi, sering terjadi sangat cepat bersamaan dengan terjadinya kerusakan lingkungan. Sebaliknya, pemulihan kerusakan lamun, baik dengan pertumbuhan secara horizontal melalui pertambahan panjang rhizoma maupun dengan pertunasan, terjadi sangat lambat dan mencapai tahunan atau puluhan tahun (Bryars dan Neverauskas, 2004). Kerusakan habitat lamun akan menimbulkan kerusakan habitat pesisir lainnya seperti mangrove dan terumbu karang, yang lambat laun akan mengancam keseimbangan sumberdaya dan ekosistem pesisir. Salah satu cara untuk mengimbangi cepatnya laju kerusakan habitat lamun adalah dengan mengembangkan dan menerapkan teknologi transplantasi lamun di habitat pesisir.
Tujuan penelitian ini adalah mengetahui perubahan luas penutupan padang lamun dan mengetahui lokasi yang sesuai untuk donor dan penerima transplantasi lamun di Gugusan Pulau Pari, Kepulauan Seribu, DKI Jakarta.

\section{Metode Penelitian}

Penelitian ini dilaksanakan pada April-Mei 2008, meliputi pengolahan data citra, data akustik dan survei lapangan. Survei lapangan dilakukan pada tanggal 18-20 Juni 2008 di gugus Pulau Pari, Kepulauan Seribu, Jakarta (Gambar 1). Parameter Fisika-Kimia perairan dianalisis di Laboratorium Produktivitas Lingkungan, Fakultas Perikanan dan Ilmu Kelautan, IPB.

\section{Analisis Kerapatan dan Penutupan Padang Lamun}

Kerapatan lamun pada lokasi penelitian diukur dari jumlah tunas yang terdapat dalam transek kuadrat ukuran $1 \times 1 \mathrm{~m}^{2}$ sebanyak empat kali ulangan, sehingga rumus yang digunakan adalah (Brower dan Zar, 1977):

$$
\mathbf{D}=\mathbf{n i} / \mathbf{A}
$$

Keterangan : $\mathrm{D}=$ Kerapatan jenis (individu $/ \mathrm{m}^{2}$ ) $\mathrm{ni}=$ Jumlah total individu jenis-i $A=$ Luas area pengamatan $\left(\mathrm{m}^{2}\right)$

Luas area penutupan jenis lamun tertentu dihitung dengan menggunakan petak contoh yang digunakan untuk pengambilan contoh berukuran $50 \mathrm{~cm} \times 50 \mathrm{~cm}$ yang masih dibagibagi menjadi 25 sub petak, berukuran $10 \mathrm{~cm}$ x $10 \mathrm{~cm}$, kemudian dihitung luas penutupannya.

\section{Analisis Data Citra}

Analisis citra satelit terdiri dari pengolahan awal citra dan klasifikasi awal. Citra yang digunakan adalah citra Landsat. Pengolahan citra awal meliputi koreksi radiometrik dan geometrik kemudian dilakukan klasifikasi citra meliputi tanah, pasir, batu karang, dan habitat perairan dangkal seperti lamun (seagrass) serta rumput laut (seaweed). Dari hasil klasifikasi selanjutnya dilakukan pengkelasan ulang (reclass) dengan berdasar pada peta acuan dan data pendukung sehingga 
dihasilkan citra yang menampakkan kelas penutup lahan. Tahap akhir klasifikasi adalah pengujian ketelitian klasifikasi dengan perhitungan matrik kekeliruan (confussion matrix).

\section{Analisis Data Batimetri}

Data batimetri diperoleh dari hasil pengukuran di setiap kedalaman perairan secara kontinyu dengan menggunakan hydrographic echo sounder Simrad EA 500. Data akustik tentang posisi lintang dan bujur kedalaman yang diukur diperoleh secara langsung dengan menggunakan GPS (Global Positioning System).
Hasil dari pemetaan echo sounder tersebut diolah menggunakan software Surfer 8, dan hasilnya berupa kedalaman dan geomorfologi dasar perairan.

\section{Hasil dan Pembahasan}

\section{Data Citra}

Pengurangan luasan padang lamun dilakukan dengan menganalisis data citra tahun 1999 dan 2004 dengan melakukan klasifilasi unsupervised. Pada Gambar 2 disajikan peta klasifikasi supervised Gugus Pulau Pari.

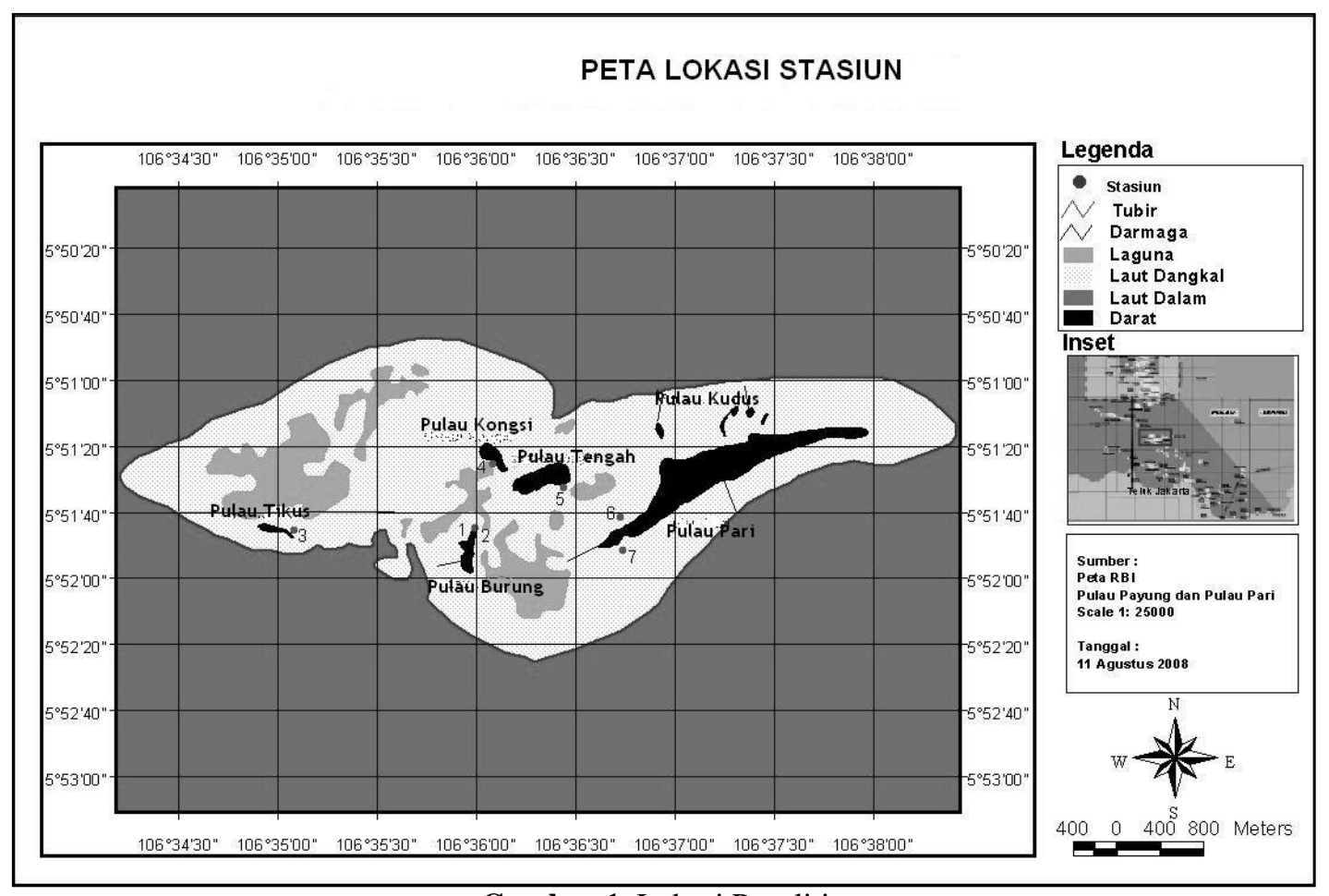

Gambar 1. Lokasi Penelitian.




Gambar 2. Peta klasifikasi Supervised.

Citra satelit Landsat 7/ETM perekaman tahun 1999 dan citra SPOT-5 perekaman tahun 2004 yang diolah dengan menggunakan klasifikasi supervised, terlihat bahwa di gugus pulau Pari terdapat sebaran lamun yang cukup luas. Lokasi lamun tersebut terlindung dari paparan laut oleh tubir. Dari pengolahan citra satelit didapatkan luasan lamun di Gugus Pulau Pari pada tahun 1999 sebesar 2,812.500 $\mathrm{m}^{2}$ dan luasan lamun pada tahun 2004 sebesar 2,134.200 $\mathrm{m}^{2}$. Diketahui terjadi pengurangan luasan lamun antara tahun 1999 hingga 2004 sebesar 678,300 $\mathrm{m}^{2}$. Oleh karena itu, untuk menjaga agar kelestarian lamun tetap terjaga harus dilakukan suatu upaya yaitu dengan melakukan transplantasi lamun.

\section{Data Batimetri}

Analisis data batimetri digunakan untuk mengetahui kedalaman suatu perairan dan peta topografinya. Berikut disajikan peta batimetri dan peta batimetri 3D (tiga dimensi) pada Gugus pulau Pari (Gambar 3).

Perairan di Gugus Pulau Pari merupakan perairan yang terlindung dari paparan laut terbuka dan dikelilingi tubir. Wilayah ini memiliki kedalaman perairan antara 0 meter dan 50 meter, dengan perairan yang dangkal di sekitar pulau-pulaunya. Vegetasi lamun di Gugus Pulau Pari merupakan vegetasi yang hidup pada perairan dangkal. Data batimetri yang diperoleh, menunjukkan bahwa vegetasi lamun yang ditemukan berada pada kedalaman kurang dari 1 meter dengan kecerahan perairan yang tinggi. Vegetasi lamun tersebar di dekat pulau sampai ke tubir.

\section{Identifikasi Lokasi yang Sesuai}

Identifikasi lokasi yang sesuai untuk penerima transplan lamun dilakukan untuk meyakinkan bahwa kondisi fisik, kimia dan biologi lokasi tersebut dapat memberikan jaminan keberhasilan uji coba transplantasi. Model yang digunakan untuk identifikasi lokasi penerima transplan adalah model yang dikembangkan oleh Short et al., (2002) dan dimodifikasi sesuai dengan kondisi lingkungan
Kepulauan Seribu. Informasi yang diperoleh berdasarkan beberapa parameter yang diukur akan dirangkum menjadi Indeks Kesesuaian Transplantasi Lamun (IKTL) yang menentukan lokasi yang menjadi prioritas. Parameter yang digunakan dalam IKTL adalah: keberadaan jenis lamun target, jarak dari lokasi donor, kecepatan arus, kecerahan, kedalaman, fraksi dan ukuran sedimen, kualitas air, kualitas sedimen. Semua parameter tersebut akan diberi skor 0,1 , atau 2 sesuai dengan kriteria pertumbuhan optimal lamun berdasarkan referensi yang tersedia.

\section{Persen Penutupan dan Kerapatan Lamun}

Luas penutupan paling tinggi dari lamun Enhalus acoroides terdapat stasiun 5 (P. Tengah) dan 6 (Utara P. Pari) yaitu 47 dan $87 \%$, lamun Thalassia hemprichii dengan luas penutupan yang tinggi ditemukan di stasiun 2 (P. Burung) dan 7 (Selatan P. Pari) dengan luas penutupan 30 dan $43 \%$, nilai kerapatan di Pulau Burung adalah $125 \mathrm{ind} / \mathrm{m}^{2}$ dan pada stasiun 7 Selatan P. Pari dengan nilai kerapatan $199 \mathrm{ind} / \mathrm{m}^{2}$. Tingkat kerapatan yang tinggi yaitu $64,51 \mathrm{dan} 75 \mathrm{ind} / \mathrm{m}^{2}$ (Tabel 1 dan 2). Lokasi dengan penutupan dan kerapatan yang tinggi tersebut berpotensi sebagai lokasi donor untuk transplantasi lamun.

\section{Kualitas Perairan}

Hasil pengukuran parameter fisika dan kimia yang berpengaruh pada pertumbuhan lamun disajikan pada Tabel 3, 4, dan 5. Dari tabel-tabel ini diketahui bahwa wilayah mayoritas lamun di gugus pulau pari terdapat pada perairan dangkal dengan tingkat kecerahan yang mencapai $100 \%$, sehingga memungkinkan cahaya matahari menembus kolom perairan. Kedalaman perairan dan intensitas cahaya yang masuk dalam perairan berpengaruh terhadap proses fotosintesis lamun.

Wilayah lamun di pulau Pari merupakan wilayah yang terlindung dari paparan laut lepas sehingga arus yang mengalir di wilayah tersebut cenderung rendah bahkan hampir tidak ada (perairan tenang), sehingga lamun dapat tumbuh dengan baik. Suhu perairan berkisar antara $28,7-35,8^{\circ} \mathrm{C}$. Kisaran nilai suhu yang cukup 
tinggi tersebut dikarenakan topografi perairan yang dangkal sehingga sinar matahari mampu menembus sampai dasar perairan.

Nilai parameter kimia yang diperoleh, wilayah lamun di gugus pulau Pari memiliki kadar oksigen terlarut yang baik antara 6,7-9 $\mathrm{mg} / \mathrm{L}$. Rentang salinitas diperoleh antara 29-32 $\%$. Kadar fosfat yang diperoleh berada di bawah nilai baku mutu air yaitu 0,015 mg/l (Kep.Men 179/Men.KLH/ 2004). Fosfat dihasilkan dari pemecahan fosfor oleh organisme dalam substrat. Ketersediaan fosfat dalam perairan berperan terhadap pertumbuhan akar, pembentukan bibit, fotosintesis, dan respirasi. Selain fosfat diketahui bahwa kadar nitrat berada di bawah nilai baku mutu air yaitu $0.008 \mathrm{mg} / \mathrm{l}$ kecuali pada stasiun 1, 2, dan 5 (Kep.Men 179/Men.KLH/ 2004). Nitrat dalam perairan merupakan turunan dari nitrogen. Fungsi nitrogen pada tumbuhan adalah memacu pertumbuhan, dan sintesis asam amino serta protein namun karena lamun adalah tumbuhan air, nitrogen harus diubah menjadi bentuk anorganik berupa nitrat dan amonium supaya dapat dimanfaatkan.

Substrat pada tujuh stasiun tersebut didominasi oleh pasir. Tekstur pasir antara 89,49-96,93\%. Fraksinasi sedimen memengaruhi sistem perakaran pada lamun. Lamun yang hidup di daerah substrat berpasir cenderung memiliki perakaran yang lebih kuat dari pada lamun yang hidup pada substrat yang berlumpur. Hal ini karena tingkat porositas pasir yang besar dan seragam sehingga akar perlu mencengkeram kuat substrat supaya dapat bertahan dari arus dan gelombang.

Total C-organik berkisar antara 12,65-25,80 mg/L. Total C-Organik makin tinggi pada daerah dengan kepadatan lamun yang tinggi (Effendi, 2003). Hal tersebut dapat disebabkan semakin padat suatu padang lamun maka semakin banyak jumlah daun tua yang meluruh dan membusuk. Jumlah C-Organik dalam air tergantung pada waktu dan jumlah bahan organik busuk yang tersedia.

\section{Indeks Kesesuaian Transplantasi Lamun}

Indeks Kesesuaian Transplantasi Lamun (IKTL) dilakukan guna menentukan lokasi donor transplantasi lamun. Berdasarkan Tabel 6, didapat hasil bahwa wilayah dengan skor yang paling rendah merupakan wilayah yang tidak sesuai untuk kegiatan transplantasi lamun. Wilayah tersebut adalah stasiun 3 dan 4 . Adapun wilayah yang sangat sesuai untuk dijadikan donor transplan adalah stasiun 5 dan 6 untuk lamun jenis Enhalus acoroides dan stasiun 2 dan 7 untuk lamun jenis Thalassia hemprichii.

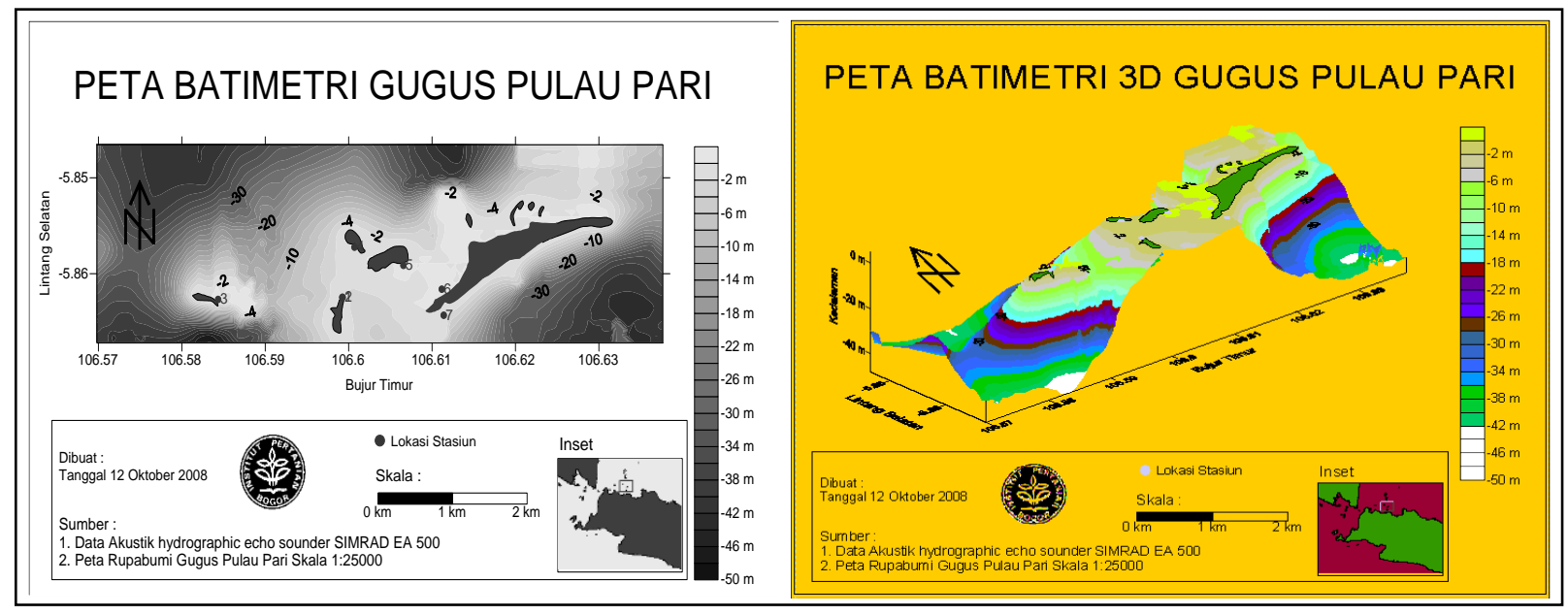

Gambar 3. Peta Batimetri dan Batimetri 3D (tiga dimensi).

Tabel 1. Persen penutupan Lamun (\%)

\begin{tabular}{clcccc}
\hline \hline No. & \multicolumn{1}{c}{ Stasiun } & Enhalus & Thalassia & Cymodocea & Halodule \\
\hline \hline 1. & P. Burung & 10 & 0 & 0 & 0 \\
2. & P. Burung & 0 & 30 & 0 & 2 \\
3. & P. Tikus & 13 & 17 & 2 & 42 \\
4. & P. Kongsi & 22 & 2 & 0 & 0
\end{tabular}




\begin{tabular}{|c|c|c|c|c|c|}
\hline & & 5 & 4 & 0 & 0 \\
\hline 5. & P. Tengah & 47 & 0 & 0 & 0 \\
\hline 6. & Utara P. Pari & 87 & 0 & 0 & 0 \\
\hline 7. & Selatan P. Pari & 0 & 43 & 0 & 0 \\
\hline$\overline{\text { Tabel }}$ & $\overline{\text { Kerapatan Lamu }}$ & & & & \\
\hline No. & Stasiun & Enhalus & Thalassia & Cymodocea & Halodule \\
\hline 1. & P. Burung & 64 & 0 & 0 & 0 \\
\hline 2. & P. Burung & 0 & 125 & 0 & 49 \\
\hline 3. & P. Tikus & 11 & 15 & 2 & 79 \\
\hline 4. & P. Kongsi & 20 & 6 & 0 & 0 \\
\hline & & 7 & 12 & 0 & 0 \\
\hline 5. & P. Tengah & 51 & 0 & 0 & 0 \\
\hline 6. & Utara P. Pari & 75 & 0 & 0 & 0 \\
\hline 7. & Selatan P. Pari & 0 & 119 & 0 & 0 \\
\hline
\end{tabular}

Tabel 3. Parameter fisika perairan.

\begin{tabular}{clcccc}
\hline \hline No. Stasiun & \multicolumn{4}{c}{ Parameter Fisika } \\
\cline { 3 - 6 } & & Suhu $\left({ }^{\circ} \mathbf{C}\right)$ & Kecepatan Arus $(\mathbf{m} / \mathbf{s})$ & Kedalaman $(\mathbf{c m})$ & Kecerahan $(\%)$ \\
\hline \hline 1. & P. Burung & 31,3 & 0.04 & 43 & 100 \\
2. & P. Burung & 31,3 & 0.04 & 43 & 100 \\
3. & P. Tikus & 28,7 & 0.02 & 50 & 100 \\
4. & P. Kongsi & 30,3 & 0 & 33 & 100 \\
5. & P. Tengah & 32,1 & 0 & 50 & 100 \\
6. & Utara P. Pari & 34 & 0 & 40 & 100 \\
7. & Selatan P. Pari & 35,8 & 0 & 10 & 100 \\
\hline \hline
\end{tabular}

Tabel 4. Pengukuran parameter kimia perairan.

\begin{tabular}{|c|c|c|c|c|c|}
\hline \multirow[t]{2}{*}{ No. } & \multirow[t]{2}{*}{ Stasiun } & \multicolumn{4}{|c|}{ Parameter Kimia } \\
\hline & & Salinitas $\left({ }^{0 /} /{ }_{00}\right)$ & DO $(\mathrm{mg} / \mathrm{L})$ & Fosfat (mg/L) & Nitrat $(\mathrm{mg} / \mathrm{L})$ \\
\hline 1. & P. Burung & 29 & 6,7 & $2<0,0001$ & 0,1 \\
\hline 2. & P. Burung & 29 & 6,7 & $<0,0001$ & 0,1 \\
\hline 3. & P. Tikus & 31 & 6,9 & 0 & $<0,0001$ \\
\hline 4. & P. Kongsi & 29 & 8,3 & 0 & 0 \\
\hline 5. & P. Tengah & 31 & 9 & 0,01 & 0,02 \\
\hline 6. & Utara P. Pari & 31 & 8,5 & 0,01 & 0,01 \\
\hline 7. & Selatan P. Pari & 32 & 8,1 & 0 & 0 \\
\hline
\end{tabular}

Tabel 5. Nilai parameter fisika kimia substrat.

\begin{tabular}{clrccc}
\hline \hline \multirow{2}{*}{ No. Stasiun } & \multicolumn{3}{c}{ Parameter } \\
\cline { 3 - 6 } & & \multicolumn{2}{c}{ Tekstur (\%) } & Total C-organik \\
\cline { 3 - 6 } & & Pasir & Debu & Liat & Mg/L \\
\hline \hline 1. & P. Burung & 90,13 & 7,24 & 2,63 & 24,90 \\
2. & P. Burung & 89,49 & 9,44 & 1,07 & 22,65 \\
3. & P. Tikus & 95,06 & 1,82 & 3,11 & 14,75 \\
4. & P. Kongsi & 96,71 & 1,63 & 1,66 & 14,60 \\
5. & P. Tengah & 94,71 & 2,98 & 2,31 & 25,80 \\
6. & Utara P. Pari & 93,66 & 5,03 & 1,31 & 22,40 \\
7. & Selatan P. Pari & 96,93 & 1,51 & 1,56 & 12,65 \\
\hline \hline
\end{tabular}

Tabel 6. Skoring lokasi penelitian.

\begin{tabular}{clcccccccc}
\hline & Parameter & Bobot $(\boldsymbol{\%})$ & \multicolumn{5}{c}{ Lokasi (Stasiun) } \\
\cline { 4 - 9 } & & & $\mathbf{1}$ & $\mathbf{2}$ & $\mathbf{3}$ & $\mathbf{4}$ & $\mathbf{5}$ & $\mathbf{6}$ & $\mathbf{7}$ \\
\hline \hline 1. & Arus & 20 & 2 & 2 & 2 & 2 & 2 & 2 & 2 \\
2. & Substrat & 20 & 2 & 2 & 2 & 2 & 2 & 2 & 2 \\
3. & Kecerahan & 10 & 2 & 2 & 2 & 2 & 2 & 2 & 2 \\
4. & Kedalaman & 10 & 2 & 2 & 2 & 2 & 2 & 2 & 1 \\
5. & Kualitas Air & 10 & 1 & 1 & 2 & 1 & 2 & 2 & 2
\end{tabular}




\begin{tabular}{llcccccccc} 
6. & Keberadaan Jenis Lamun Target & 10 & 2 & 2 & 1 & 1 & 2 & 2 & 2 \\
7. & Penutupan & 10 & 1 & 1 & 1 & 2 & 2 & 2 & 2 \\
8. & Kerapatan & 10 & 2 & 2 & 1 & 1 & 1 & 2 & 2 \\
\hline \hline & Total Skor & & $\mathbf{1 , 8}$ & $\mathbf{1 , 8}$ & $\mathbf{1 , 7}$ & $\mathbf{1 , 7}$ & $\mathbf{1 , 9}$ & $\mathbf{2}$ & $\mathbf{1 , 9}$ \\
\hline
\end{tabular}

Simpulan dan Saran

\section{Simpulan}

Berdasarkan hasil penelitian dapat disimpulkan nilai penurunan luasan padang lamun di Gugus Pulau Pari antara tahun 1999 dan 2004 seluas $678.300 \mathrm{~m}^{2}$. Perairan di Gugus Pulau Pari memiliki kedalaman perairan antara 0 meter hingga 50 meter, dengan perairan yang dangkal di sekeliling pulau-pulaunya. Hasil analisis IKTL lokasi yang sesuai untuk donor transplantasi lamun adalah stasiun 5 dan 6 untuk lamun jenis Enhalus acoroides dan stasiun 2 dan 7 untuk lamun jenis Thalassia hemprichii.

\section{Saran}

Saran yang perlu dilakukan adalah melakukan pemetaan padang lamun pada seluruh perairan Kepulauan Seribu setiap tahunnya guna mendapatkan data perubahan luas penutupan lamun yang lebih akurat.

\section{Ucapan Terima Kasih}

Ucapan terima kasih ditujukan kepada Direktorat Jendral Pendidikan Tinggi (DIKTI), DEPDIKNAS atas bantuan dana penelitian melalui program penelitian Hibah Bersaing No. 212/13.11/PL/2008.

\section{Daftar Pustaka}

Borum, J., Sand-Jensen, K., Binzer, T., Pedersen, O. dan Greve, T.M. 2006. Oxygen Movement in Seagrasess. In: Larkum, A.W.D., Orth, R.J., Duarte, C.M. (Eds.). Seagrasess: Biology, Ecology and Conservation. Pp. 255-270. Springer, The Netherlands.

Brower, J.E. dan Zar, J.H. 1977. Field and Laboratory Methods for General Ecology. WM. J. Brown Company Publ. Dubuque. Iowa. 94 p.

Bryars, S. dan Neverauskas, V. 2004. Natural recolonisation of seagrass at a disused sewage sludge outfall. Aquatic Botany, 80: 283-289.

Den hartog, C. 1996. Sudden Declines of Seagrass Bed: "Wasting Disease" and Other Disaster. In:
Kuo, J., Phillips, R.C., Walker, DI., Kirkman, H. (eds.) Seagrass Biology: Proceedings of an International Workshop, Rottnest Island, Western Australia, 25-29 January 1996. pp 309314

Duarte, C.M. 2002. The Future of seagrass Meadows. Environmental Conservation, 29: 192-206.

Effendi, H. 2003. Telaah Kualitas Air Bagi Pengelolaan Sumber Daya dan Lingkungan Perairan. Penerbit Kanisius Yogyakarta.

Fonseca, M.S. dan Fisher, J.S. 1986. A Comparison of Canopy Friction and Sediment Movement Between Four Species of Seagrass with Reference to Their Ecology and Restoration. Marine Ecology Progress Series 29, 15-22.

Preen, A.R., Lee Long, W.J. dan Coles, R.G. 1995. Flood and Cyclone Related Loss, and Partial Recovery of More Than $1000 \mathrm{~km}^{2}$ of Seagrass in Hervey Bay, Queensland, Australia. Aquatic Botany, 52: 3-17.

Robblee, M.B., Barber, T.R., Carlson, P.R., Durako, M.K., Fourqurean, J.W., Muehlstein, L.K., Porter, D., Yarbo, L.A., Zieman, R.T. dan Zieman, J.C. 1991. Mass Mortality of The Tropical Seagrass Thallassia testidinum in Florida Bay (USA). Marine Ecology Progress Series, 71: 297-299.

Short, F.T. dan Wyllie-Echeverria, S. 1996. Natural and Human Induced Disturbances of Seagrass. Environmental Conservation 23, 17-27.

Short, F.T., Davis, R.C., Kopp, B.S., Short, C.A. dan Burdick, D.M. 2002. Site Selection Model for Optimal Restoration of Eelgrass, Zostera Marina L. Marine Ecology Progress Series, 227: 253-267.

Seddon, S., Connoly, R.M. dan Edyvane, K.S. 2000. LargeScale Seagrass Dieback in Northern Spencer Gulf, South Australia. Aquatic Botany, 66: 297-310.

Seddon, S. Miller, D., Fotheringham, D., Burges, S. dan McKechnie, J. 2003. Beachport Seagrass Loss and Link with Drain $M$ in the Wattle Range Catchment. Prepare for the Coast Protection Board, Department of Enviromental and Heritage and Environment Protection Authory. South Australian Research and Development Intitute (Aquatic Sciences), Adelaide. Publication no. RD03/0190.

Romero, J.K., Perez, M., Mateo, M.A. dan Alcoverro, T. 2006. Seagrass Biology, Ecology and Conservation. In: Larkum, A.W.D., Orth, R.J., Duarte, C.M. (Eds.). Pp 227-254. Springer, The Netherlands. 
Walker, D.I., Kendrick, G.A. dan McComb, A.J. 2006. Decline and Recovery of Seagrass Ecosystemsthe Dynamics of Change. In: Larkum, A.W.D., Orth, R.J. and Duarte, C.M. (Eds.) Seagrasses: Biology, Ecology and Conservation. $\mathrm{Pp}$ 551-565. Springer, The Netherlands. 